DOI: 10.21625/resourceedings.v2i3.619

\title{
Giuseppe Zander restorer. The methodological approach to the conservation project
}

\author{
Cesare Crova ${ }^{1}$ \\ ${ }^{1}$ National Institute of Preservation and Restoration, Ministry for Cultural Resources and Activies, Rome, Italy.
}

Email: cesare.crova@libero.it

\begin{abstract}
Giuseppe Zander was the "Proto" of the "Fabbrica di San Pietro": the architect who undertook the restoration of the most important complex of Christianity, after being a member of the Pontifical Commission of Sacred Art in Italy.

In this capacity, the approach to the monument for Zander was of absolute respect, the knowledge of the architectural work was acquired through real sketches, annotations on the formal and constructive aspects, the building phases, the materials used, the degradation. The direct investigation was accompanied by the theoretical study with the bibliographic and archival research, from which derived the critical synthesis contained in his notebooks. From these studies emerges the full mastery of the subject and the opportunity to understand the context by an audience not necessarily made of experts, using a simple and immediate language, but at the same time cultured, full of classic quotations, from which emerges his figure of humanist.
\end{abstract}

His designer activity as a restorer remains in all his projects, from which the mentioned concepts are outlined, with his careful theoretical reflection that precedes the restoration project, in which he acquires the values of the past architecture transposing them into modern forms through the use of modern techniques and technologies, in perfect union with construction techniques and local typological habits.

Among many projects, we focus on the restoration of the "Collegiate Church of San Pietro" in Minturno (1966-67), in which we find the synthesis of the methodological path of Giuseppe Zander.

(C) 2019 The Authors. Published by IEREK press. This is an open access article under the CC BY license (https://creativecommons.org/licenses/by/4.0/).

\section{Keywords}

Giuseppe Zander; Conservation; Preservation; Restoration; Collegiate Church of San Pietro

\section{Introduction}

Giuseppe Zander was an architecture historian, a renowned professor, meticulous philologist and tireless investigator, but also a restorer and as such he worked achieving unique and specific results. The fate of every architecture historian, that is extending his action from the philological-critical study to the entire restoration process, is materialized in him for various reasons: because restoration is a work whose phases must be guided and regulated according to the results of the historical study on the monument; because the historian dealing with these investigations is an architect led to propose solutions that arise as results of his work; because the historian-architect as author of the historical-critical study of the building is the most qualified person to design and manage the restoration works (Bonelli 1993, p. 11). He was a designer involved in the whole disciplinary range of architecture, 
from the urban to the building scale, from the public works to the economic housing and, especially, to the worship buildings, as well as, for what concerns this essay, in the restoration activities.

Last direct student of Gustavo Giovannoni, he got from him those teachings that, leading to the birth of the Roman School, were the solid basis of his education that will reverberate in his professional practice. In fact, he developed with Giovannoni a new concept of architecture history, once prerogative of art historians and now intensely and rigorously cultivated by scholars with a different background. So it was needed to create a relationship between the architecture as a moment of doing and the architecture history as a reflection on what there was before the moment of doing. Regarding this issue, there was a controversy with Adolfo Venturi who affirmed that the architectural works had to be considered as any other work of art (sculpture and painting), a concept denied by Giovannoni who believed that it was not possible to make just mere aesthetic assessments, because it was needed to adopt investigatve methods obtainable right from the building as an artifact, even a technical one. So that proclaimed the disciplinary autonomy of architecture (Franchetti Pardo 1991, p. 216-17).

According to Zander's opinion, the monument is therefore a document to be deeply studied as a text, to be examined onsite, to be directly analyzed first as an "individual" and then as a technical-artistic product belonging to a historical period. So the architecture must be observed giving importance to its typical and unique components: construction techniques, materials, dimension relationships, language elements, stasis issues, considering the work as a specific result of the planning and construction process, that receives an accurate critic of the text, and not as an aesthetic object (Franchetti Pardo 1991, p. 220).

As an architecture graduate (1946) he immediately became assistant professor of the course of History of Art and History and Styles of Architecture held by Vincenzo Fasolo, with whom he improved his talent in freehand drawing. At the same time he show interest in the restoration field and in 1948 took over from Gustavo Giovannoni in the important restoration work of the church of San Giovanni Battista in Formia (Latina). In fact, in addition to his studies of the architecture history and to the design activities, he dedicated himself to this field intensely, especially when he was thirty-one years old and worked on the parish complex of San Leone Magno in Rome (1951-52), later promoted to the rank of titular basilica, an unusual event for a still living architect (Muñoz 1953, p. 30-36, Longhi 2010, p. 13132). His working activities allowed him to be appointed Resident Consultant of the Pontifical Central Commission for Sacred Art in Italy (1955) and, after his appointment as a professor in History of Architecture, he was nominated from Pope John Paul II Director of the Technical Office of the Reverend Fabric of Saint Peter in the Vatican (1981). Here, following his theoretical principles, he managed, among others, the restoration of the façade planned by Carlo Maderno (April 1985-November 1986), with minimal, calibrated works, paying attention to the maintenance of the façade in its plastic and urban configuration defined through the centuries, respecting the historical and figurative look that the monument acquired with the settlement over the years and the improvement that the time gave to its architectural image. It was then possible to obtain the best "current state of ancient matter" rather than the restoration of an image lost through the centuries.

Here we dwell upon the analysis of the restoration of the Collegiate Church of San Pietro a Minturno (Latina) in which we find the methodological path of Giuseppe Zander work, which from the philological-critical study reaches the entire conservation process, where the architecture-restoration synthesis is an unique artistic and operative moment.

\section{The collegiate church of San Pietro}

Minturno is located in the southern end of Lazio, close to the administrative border of Campania, and until 1927 it was part of the Norman origin province called Terra di Lavoro, going from the current province of Caserta in the south and up to Terracina in the north. The Medieval village of Traetto (Minturno since 1879) is situated on a hill overlooking the Gulf of Gaeta, to the west, and the plain of Garigliano until the promontory of Monte Massico, to the east. The church of San Pietro is centrally-located, on the highest place of the village, not far from the fortress. The planimetric layout compared to the urban planning of the inhabited area follows the morphology of the medieval centers, where the church was placed tangentially to the main course (Fig 1-2) (Crova 2002, p. 27-36). 


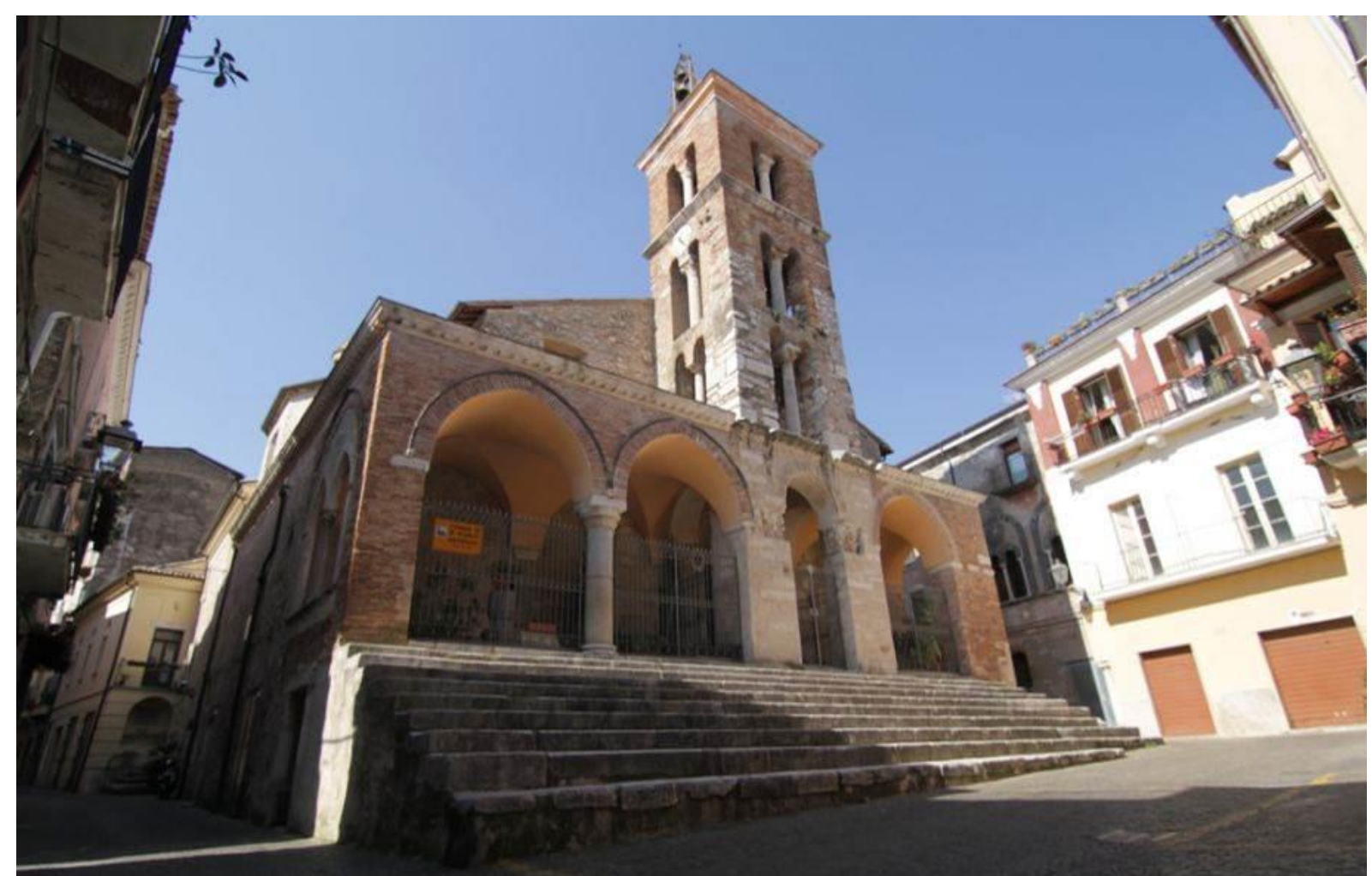

Figure. 1. Minturno (LT), Collegiate Church of San Pietro (Photo by A.).

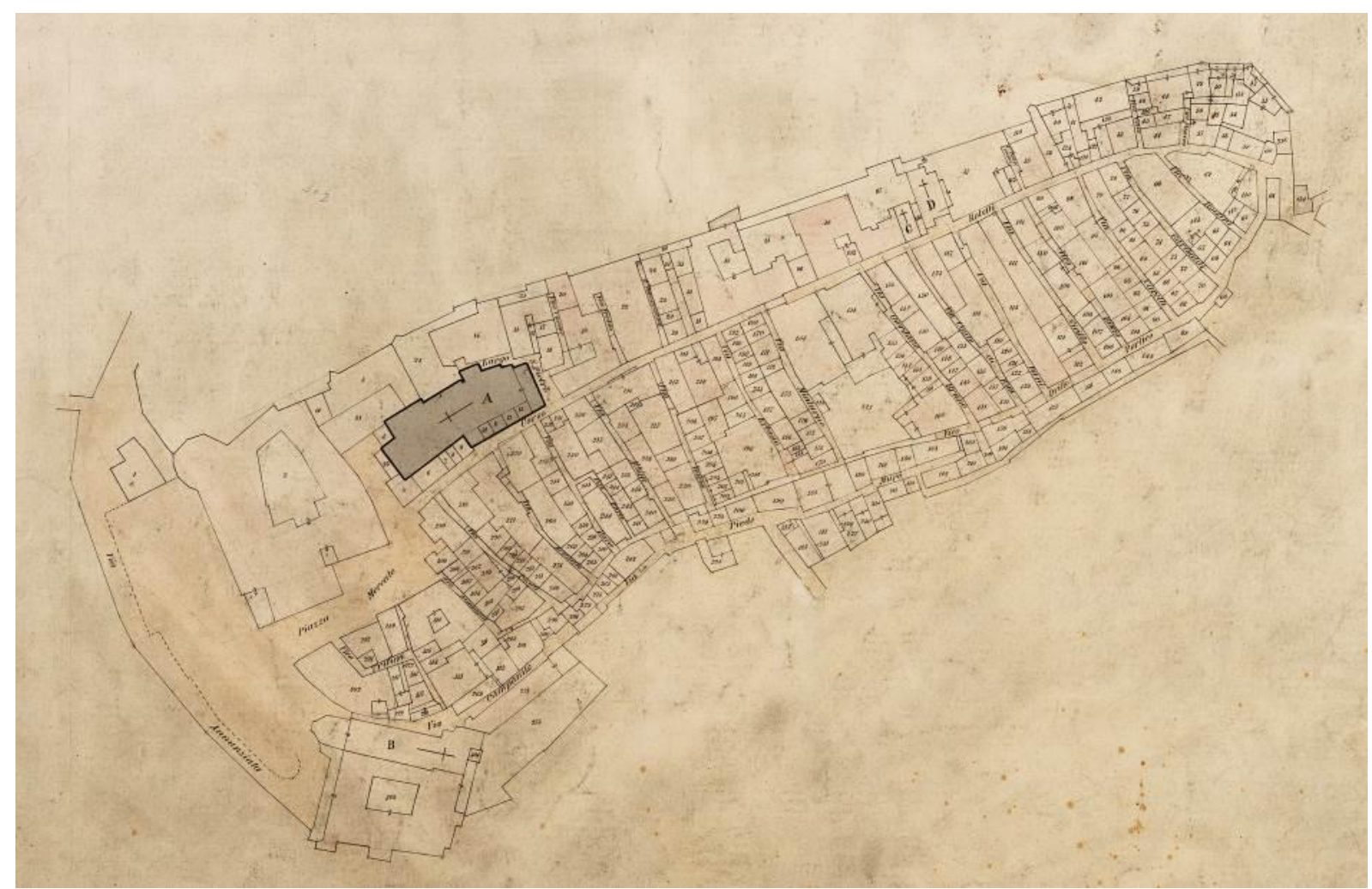

Figure. 2. Minturno, urban map in 1880.

The building is preceded by a wide staircase and its façade is characterized by a bell-tower in axis, built on three floors separated by simple mouldings and marked by mullioned windows, and by a porch formed by two porticoes that are different from the central one.

Thanks to the preliminary study, bibliographic and archival, and to the results of the direct study of the complex 
during the restoration works, Giuseppe Zander defined the chronology, until now the most reliable, which can be summarized in seven construction phases (Fig. 2). In fact, the restoration works often give the opportunity to reconsider the artistic values of a monument, its historical location and to investigate its construction history again, enriching the philological knowledge of the architectural work (Zander 1976, p.19). What emerges is a rather complex story of the medieval historical formation of the Minturno complex, whose construction phases are limited to the period that goes from the tenth to the fourteenth and fifteenth centuries (ignoring consciously chapels and altars from sixteenth and seventeenth centuries), and with its most important nucleus dating back to the mid-twelfth century, an information born with the studies of early twentieth century and others later made in particular on the bell tower (1899-1901) (Avena 1902, p. 179, Abatino 1903, p. 56-59, Rosi 1949, p.13), while the only cornerstone is the inscription on the candelabrum of the Paschal candle (1264) (Zander 1976, p. 26). The chronology proposed by Zander is now updated, following the studies on the church, updated to the present day. Starting from the work of the Roman architect, fourteen construction phases are identified, including those relating to the restoration works of Gino Chierici (1926) and of Giuseppe Zander himself (Fig. 3) (Volpe 1990, p. 24-46; Crova 2017).
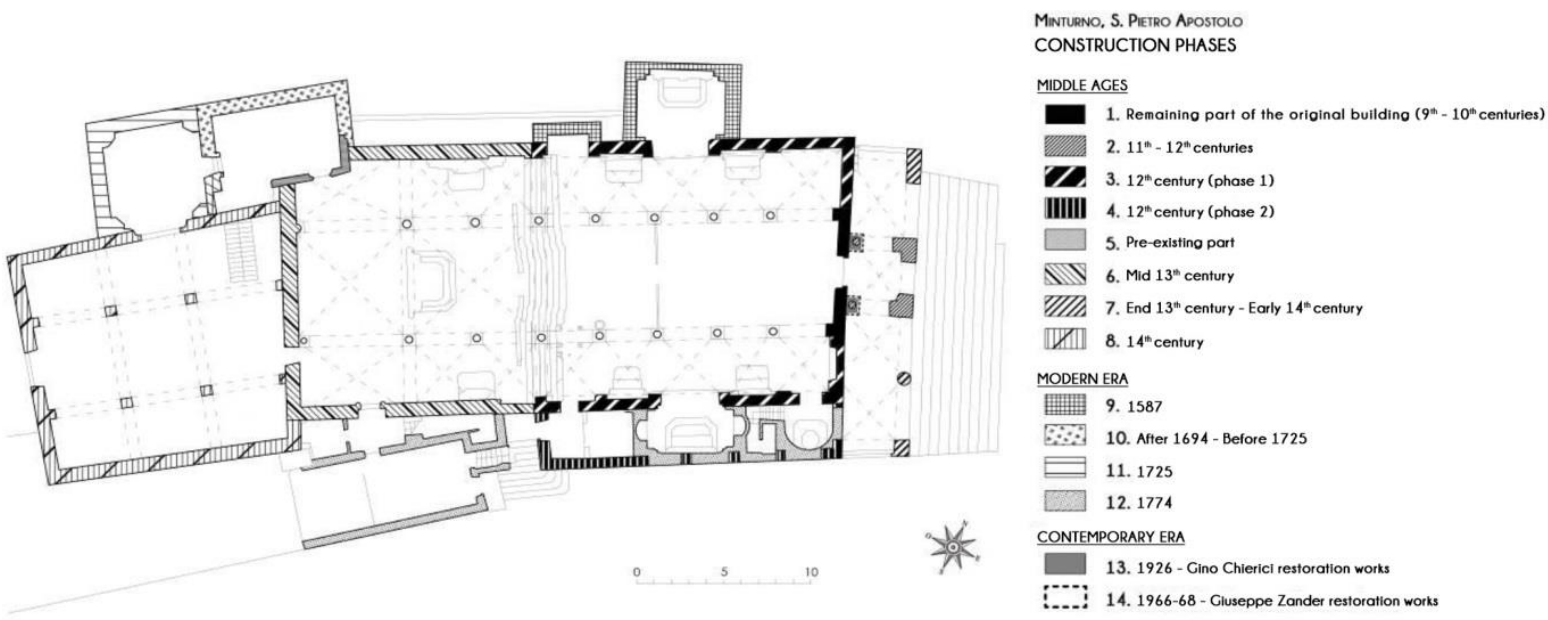

Figure. 3. Minturno (LT). Collegiate Church of San Pietro. Construction phases (from Crova 2017).

\section{The restoration project. Theoretical reflections and method issues}

Giuseppe Zander designed and managed the restoration works between the years 1966-68, following those that had involved the church in 1902, managed by Giuseppe Abatino (Abatino 1903, p. 56-59), those between 1926 and 1932 by Gino Chierici, commissioned by the then Minister of Public Education, the Minturno citizen Pietro Fedele, and lastly those in the Fifties related to the damage suffered in the Second World War that were commissioned by the Superintendency of the Monuments of Lazio and managed by the architect Raffaele Perotti (ASABAP Archive). Zander's works had three purposes: to reinforce the bell tower, which revealed stasis problems, and make the columns close to the door free from the pillars, which had covered them in the first half of the century; to find out the causes that determined the moisture in the back wall of the church; to repair the roofs.

The project report, dated April 21, 1966, is written by him on a glossy paper roll and is composed of 38 pages, where he makes full use of freehand drawing, which he considered the most suitable tool to investigate architectural phenomena and, above all, to talk about architecture. The structure of his report immediately makes clear the methodological rigor that guides the historical and direct study, at the base of the restoration project. Here he mentiones first the bibliography that he consulted and that he wrote in chronological order, followed by the summary, the introduction and the report, which is itself divided into two main chapters: Static stabilization and works to eliminate the moisture and Aesthetic problems of the architectural restoration (Zander 1966).

The scientific accuracy that guides the project emerges immediately, as well as the attention that Giuseppe Zander gives to the direct study of the complex and to the information deduced from it, investigating the structure as reading 
a book: the architectural organism, therefore, as a document of itself (Zander 1971). Much attention is paid to the bell tower, which revealed statis problems, from whose direct evaluation emerges that it was built with the truncated pyramidal taper of the external walls, while the internal wall prism does not have any set-backs; moreover, a slight overhanging of about $2 \mathrm{~cm}$ at the top is due to constructive inaccuracies, as there are no indicative lesions that explain this irregularity. The investigation went through four diagnostic excavations, which revealed a good quality of the foundations, and through the study of both foundation and raised walls, which showed that they were not completely homogeneous and bound with a heterogeneous quality mortar. The final choice, even after a statis consultation, was to keep the works made by Gino Chierici with Pietro Fedele at the end of the Twenties unaltered, because otherwise they would have been corroborated by this restoration, and intervening just on the columns leaning against the façade to make them free from the superstructures, that were temporary anyway, so that the medieval columns would have been unloaded thanks to iron pillars hidden behind the façade that will unload theirself the weight on different foundation sections. Instead, the bell tower was reinforced by means of steel bars in the first level, there was a limited snip-and-fix of the walls and the insertion of steel slabs in the upper landings, replacing the reinforced concrete, which did not lend itself to the geometric shape of the bell tower. In the stabilization project it was also considered the borne load of the bells and for this reason it is called the engineer Lucenti who in the past had dealt with more complex projects, as for Gaeta, Anagni or Rome (S. Maria in Cosmedin, S. Lorenzo in Damaso, etc.). Still regarding the outside area, Zander does not complete the church staircase, firstly because it would mean to restrict unacceptably the medieval alley, characterized by the remains of the Campania-Normandy façades that overlook it, as well as to have no certainty of the staircase completion; secondly because of the lack of strong functional necessities that required it, so the addition of new parts was not justified. Other works to stabilize the structure involved the sacristy where the vault was secured by removing many debris that weighed on it, but not the ones present in the sides, where their positive static function had not to be altered.

As far as the moisture is concerned, here too the works go through a preliminary study of the places condition, from which it emerges that most of the problems stemmed from the absence, for a decade, of the oratory coverage and from the presence of a lot of demolition remainings hastily piled up in the burial ground under the oratory after the Second World War. That had facilitated the penetration and stagnation of rainwater and allowed its capillary rise in the walls. The problem was solved by the debris removal, creating ventilation grids in the ossuary area and a limestone drainage on the side of the masonry towards the church presbytery.

The limited distance between the walls of the sacristy and the one of the nearby house, about one meter, which recalls the medieval law that did not admit sharing walls, had allowed the accumulation of brambles and rubbish, in addition to the stagnation of water, on the outside. In order to overcome all that, Zander designs a drainage channel that is protected and with slopes that allow the flow of water towards suitable orifices. Moreover, there was the problem of the last column on the right that was off its axis (in the nave of the church) and situated at the end of the church, next to the main altar. Here, a careful analysis of the context, accompanied by an excavation and several reflections on the static cross-sectional scheme of the church, beyond the conclusions of the previous restoration works, lead Zander not to consider the straightening of the column as urgent.

The second part of the project is dedicated to the aesthetic problems of the restoration works. Here too, Zander brings out all his historical expertise and critical approach to the problem of reintegration. If it is allowed to plaster the bell tower, because of the traces of remainings that can be observed, attributable to the Chierici-Fedele restoration works, but also for what can be observed in the drawings of Abatino of 1902 (Abatino 1903, p. 59), and because of the poor quality of the roughly constructed masonry, which lead to build a tower bell that follows the irregularities of the medieval wall surfaces, spreading the plaster by hand and with the patch (work that will not be realized), a different speech must be done for the portico, built after the bell tower it is leaning against and characterized by a structure of excellent red bricks, which instead suggests to be left in sight, that is after all the scientific duty of the restorer because it is possible to read the relative chronology of the elevated elements and therefore the medieval construction events of the church. A similar reasoning is done for the surface treatment of the side part, which opened an interesting problem of the architecture history. Surely plastered in the early twentieth century, it was scratched at the time of 
Zander's restoration work. The numerous layers that can be seen and the quality of the walls suggests to redo the plaster, taking care of leaving arches and pillars and the overlapping of the porch in sight to ensure the reading of the elevated elements chronology.

The final part of the report is dedicated to the synthesis of the construction events of the Minturno complex, which Giuseppe Zander summarizes in a freehand sketch of the complex plan indicating the six construction phases he identified (updated to seven in the 1976 paper), without lingering on the chapels and altars of the sixteenth and seventeenth centuries, while in the eleventh paragraph he proposes not to intervene inside the church, limiting to essential works, in order not to veil the authenticity of the structures. The last pages are dedicated to the technical and economic framework of the works, planned for a total of forty million lire (Zander 1966).

In 1971 he completed the work with the project concerning the restoration of the oratory in archiacute forms and of the San Filippo chapel, preparing the project and the report for an expected amount of 17 million lire, a much simpler work than the previous one, which, instead, he will not deal with, refering the task to someone else (Zander 1971).

\section{Conclusions}

The work of Giuseppe Zander for Minturno highlights the attention that the architect gives to the architecture, investigating its history scrupulously, without the presumption to give definitive answers, but leaving some open questions and proposing to scholars some of his opinions as hypothesis to be verified or refuted. Starting points, pretexts for their overcoming, because, as he stated, "the restorer should feel not so much the pleasure, as the duty to give news about the results in the study, both good, bad and limited" (Zander 1976, p. 20).

This particular aspect of his method of approaching to the historical architecture restoration makes Giuseppe Zander's thinking very current, almost thirty years after his death: it should be an example to follow by the new generation of architects-restorers because an important role is taken by the study "from the real" of architecture, the freehand pencil representation, in order to catch those aspects that allow us to fully understand its constructive and typological characteristics and enter into a dialectic and respectful relationship, to operate then in the best way following the conservation project.

\section{References}

Abatino G. (1903). La cattedrale di Minturno, in «Napoli Nobilissima», p. 56-9.

ASABAP Archive: ABAP Superintendency Archive for Rome metropolitan area, Viterbo suburbs e southern Etruria. Fondo Chiesa S. Pietro a Minturno. Evaluations 629 e 713 (1953), 691 (1954), 744 (1955), 781 e 791 (1956).

Avena A. (1902). Monumenti dell'Italia meridionale. Relazione dell'Ufficio regionale per la conservazione dei monumenti delle provincie meridionali. Volume I del periodo 1891-1901, Rome: Officina Poligrafica Romana.

Bonelli R. (1993). Prefazione, in Zander G. Scritti sul restauro dei monumenti architettonici, Roma: Bonsignori, p. 9-11.

Crova C. (2002). Il centro antico di Minturno: note di urbanistica medievale, in «Civiltà Aurunca», 45-46, p. 27-36.

Crova C. (2017). La cattedrale di san Pietro apostolo a Minturno. Note sullo sviluppo della forma dell'architettura religiosa nell'Italia medievale tra IX e XIV secolo, in La costruzione della forma, architettura nell'Italia medievale, International conference of studies in honor of Corrado Bozzoni (Roma, auditorium of Architecture Faculty - Valle Giulia, 22-25 may 2017), held by Esposito D., Villa G., Viscogliosi A.

Franchetti Pardo V. (1991). Giuseppe Zander e la sua opera. Considerazioni sulla storia dell'architettura, in «Archivio della Società Romana di Storia Patria», 114, p. 215-23.

Longhi A. (2010) Cultura architettonica, vita ecclesiale e associazionismo cattolico dal dopoguerra al Concilio Vaticano II, in A. Longhi, C. Tosco, Architettura Chiesa e Società in Italia (1948-1978), Rome: Edizioni Stadium; p. 129-34.

Muñoz A. (1953). La nuova chiesa di San Leone Magno sulla via Prenestina, in «L’Urbe», n.1, p. 30-6.

Rosi G. (1949). Il campanile della cattedrale di Nola, in «Bollettino d'Arte», 1, p. 10-20.

Volpe A. (1990). Pietro Apostolo a Minturno, in «Architettura, storia e documenti», 1-2, p. 24-46,

Zander G. (1966). Architect Giuseppe Zander Archive, Restauro della Chiesa di San Pietro in Minturno. Relazione illustrata di pag. 38. Roma.

Zander G. (1971). Architect Giuseppe Zander Archive, Cassa Mezzogiorno Booklet, Superintendency Monuments of Lazio. Minturno, Church of San Pietro and oratory restoration: G. Zander, Progetto di restauro dell'oratorio in forme archiacute e della cappella di San Filippo. Relazione.

Zander G. (1976). Zander G. Precisazioni sulla chiesa di S. Pietro di Minturno, in «Bollettino del Centro di Studi per la Storia dell’Architettura», p. $19-27$. 